University of Nebraska - Lincoln

DigitalCommons@University of Nebraska - Lincoln

Publications, Agencies and Staff of the U.S.

Department of Commerce

U.S. Department of Commerce

1997

\title{
FIRST ESTIMATES OF VAQUITA ABUNDANCE
}

Jay Barlow

Southwest Fisheries Science Center, jay.barlow@noaa.gov

Tim Gerrodette

Southwest Fisheries Science Center

Greg Silber

Marine Mammal Commission

Follow this and additional works at: https://digitalcommons.unl.edu/usdeptcommercepub

Part of the Environmental Sciences Commons

Barlow, Jay; Gerrodette, Tim; and Silber, Greg, "FIRST ESTIMATES OF VAQUITA ABUNDANCE" (1997).

Publications, Agencies and Staff of the U.S. Department of Commerce. 234.

https://digitalcommons.unl.edu/usdeptcommercepub/234

This Article is brought to you for free and open access by the U.S. Department of Commerce at DigitalCommons@University of Nebraska - Lincoln. It has been accepted for inclusion in Publications, Agencies and Staff of the U.S. Department of Commerce by an authorized administrator of DigitalCommons@University of Nebraska - Lincoln. 


\title{
FIRST ESTIMATES OF VAQUITA ABUNDANCE
}

\author{
JAY BARLOW \\ Tim Gerrodette \\ Southwest Fisheries Science Center, \\ P. O. Box 271, La Jolla, California 92038, U.S.A. \\ Greg Silber \\ Marine Mammal Commission, 1825 Connccticut Avc, N.W. \#512, \\ Washington, DC 20009, U.S.A.
}

\begin{abstract}
A BSTR ACT
The abundance of the only population of vaquitas, Gulf of California harbor porpoise (Pbocoena sinus), is estimated from four surveys conducted in Mexico between 1986 and 1993, using a variety of methods. A line-transect approach was applied, using some parameters estimated from a related species, the harbor porpoise (Pbocoena phocoena). Vaquita abundance is estimated as 503 $(\mathrm{CV}=0.63)$ from $1986-1988$ boat surveys, $885(\mathrm{CV}=0.50)$ from 1988 1989 aerial surveys, $572(\mathrm{CV}=1.43)$ from a 1991 aerial survey, and 224 $(\mathrm{CV}=0.39)$ from a 1993 ship survey. A weighted log-linear regression indicates a rate of population change (decline) of $-17.7 \%$ per year $(95 \% \mathrm{CI}=$ $-43.2 \%$ to $+19.3 \%$ ) between 1986 and 1993 . All of these estimates of vaquita abundance indicate that the species is at a critically low level.
\end{abstract}

Key words: vaquita, Gulf of California harbor porpoise, Pbocoena sinus, abundance, population, line-transect survey, trends, endangered species, Mexico.

The vaquita (Pbocoena sinus) is a small porpoise and is widely recognized as the most endangered marine cetacean in the world (Klinowska 1991, Taylor and Gerrodette 1993, Vidal 1993, Bjørge and Donovan 1995). Its range is limited to the northern Gulf of California, Mexico (Brownell 1986, Gerrodette et al. 1995). The species' existence is threatened by continued incidental mortality in commercial fisheries in the Gulf. Recent mortality (1993-1994) is estimated as 39-84 vaquitas killed per year in only one of three fishing centers (D'Agrosa 1995). Given that vaquitas are rare, this mortality may be a substantial part of the population and may not be sustainable. The species may also be affected by overfishing and other anthropogenic habitat modifications in the northern Gulf of California (Barlow 1986, Villa-R. 1993). Currently, however, there is no published estimate of vaquita abundance based on systematic surveys.

Between 1986 and 1993, several surface vessel and aerial surveys were con- 
ducted for vaquitas in the northern Gulf of California. Vaquita abundance has not been estimated previously from any of these surveys for a variety of reasons: small sample size, lack of a random survey design, and violation of line-transect assumptions. Despite these deficiencies, valid abundance information was collected on all surveys. For this paper we conducted independent analyses and made four independent estimates of vaquita abundance from these surveys.

\section{Methods and Results}

A line-transect approach (Buckland et al. 1993) was used to make all abundance estimates, even though the first two series of surveys were not explicitly designed as line-transect surveys. Within a stratum, vaquita abundance, $N$, was estimated as

$$
N=\frac{A \cdot n \cdot S}{2 \cdot L \cdot W \cdot g(0)}
$$

where

$A=$ size of the study area,

$n=$ number of groups seen,

$S=$ mean or expected group size,

$L=$ length of transect line surveyed,

$W=$ the effective search width, and

$g(0)=$ probability of seeing a group directly on the transect line.

We define the effective search width, $W$, as $1 / f(0)$ [or as the inverse of the probability density function (fit to the distriburion of perpendicular sighting distances) evaluated at zero distance]. The coefficient of variation (CV) for the abundance estimate was calculated from the coefficients of variation of each variable element in Equation 1:

$$
C V(N)=\sqrt{C V^{2}(n)+C V^{2}(S)+C V^{2}(W)+C V^{2}(g(0))} .
$$

The $C V(n)$ was estimated as $\sqrt{2 n} / n$, which assumes an aggregated distribution of sightings with a variance equal to twice a Poisson variance (an approach recommended by Burnham et al. (1980) if lacking sufficient information for direct estimation). The $C V(S)$ was estimated from the standard error of the mean group size or (for the 1993 ship survey) was estimated using the regression method of Buckland et al. (1993) as implemented in the program DISTANCE (Laake et al. 1993). The $C V(W)$ [or equivalently $C V(f(0))$ ] was estimated using maximum likelihood techniques, and $C V(g(0))$ was calculated using various analytical variance estimators discussed below. Upper and lower 95\% confidence intervals for $N$ were computed from $C V(N)$, assuming a lognormal distribution (Buckland et al. 1993).

Few vaquita sightings were made on any of the surveys, making it difficult to estimate $W$ and $g(0)$ from data collected on the surveys. Therefore, the values used for $W$ (for three of the four estimates) and $g(0)$ (for all estimates) were estimated based on similar surveys in other areas for a similar species- 
the harbor porpoise (Phocoena phocoena). Vaquitas and harbor porpoises share many characteristics that affect sightability. Both are difficult to see from boats, ships, or aircraft. Both are small and typically occur in groups of three or less (Barlow 1988; Silber 1990a, b; Gerrodette et al. 1995). They surface inconspicuously, usually without a splash, and do not leap clear of the water. They surface only three to five times in a series and then dive for an average of approximately two minutes (Barlow et al. 1988, Silber et al. 1988). All studies that have been conducted on harbor porpoises have shown that the probability of seeing a group on the trackline $(g(0))$ is less than 1.0 , and this is likely to be true for vaquitas as well. To minimize bias due to missed trackline animals, we limit consideration to transects completed in "calm" sea state conditions (Beaufort 2 or less), as is typically done for harbor porpoise surveys (Barlow 1988, Barlow et al. 1988). To correct for bias due to missed trackline animals in calm seas, we estimate $g(0)$ based on studies of harbor porpoises using similar survey methods in similar conditions. When $W$ and $g(0)$ values were taken from other studies (of harbor porpoise), estimates of their CVs were also taken from the same study.

\section{Estimate \#1: 1986-1988 Pooled Boat Surveys}

Surveys werc conducted for vaquitas from an 8-m boat in spring of 1986, 1987 , and 1988 (Silber 19906). From two to four observers searched with unaided eyes and $7 \times-10 \times$ binoculars from a search height of $3.5 \mathrm{~m}$ and at a survey speed of $10-11 \mathrm{~km} / \mathrm{h}$. Surveys were conducted only in calm weather, and $1,994 \mathrm{~km}$ of transect were completed in Beaufort sea states of 2 or less. Effort was concentrated non-randomly in areas where vaquita density was thought to be high; therefore, transects were post-stratified to give four strata which contained approximately uniform survey effort (Fig. 1). Line-transect methods were not used on these surveys, so we estimate $W$ and $g(0)$ by comparison to similar surveys conducted elsewhere for harbor porpoises.

To aid in estimating $W$ and $g(0)$, we summarize results of several past vessel surveys for harbor porpoises. Batlow (1988) conducted a ship survey for harbor porpoises in California, Oregon, and Washington using a 52-m survey vessel with five observers searching from a height of $10 \mathrm{~m}$ with a combination of $7 \times$ binoculars and unaided eyes. He estimated effective search widths (W) of 222 and $143 \mathrm{~m}(\mathrm{CV}=0.22$ and 0.19 , respectively) in Beaufort $0-1$ and Beaufort 2, respectively, and estimated the probability of seeing a trackline group $(g(0))$ to be $0.78(\mathrm{CV}=0.15)$. Calambokidis et al. (1990) conducted a boat survey for harbor porpoises in central California using 10-13-m vessels with three observers searching with $7 \times$ binoculars and unaided eyes from an observation height of $4.5 \mathrm{~m}$. They estimated an effective search width of 370 $\mathrm{m}(n=81, \mathrm{CV}=0.11)$ for Beaufort 0 and 1. Calambokidis (in press)' conducted ship surveys for harbor porpoises off the coast of Washington using $11-\mathrm{m}$ boats with three observers searching with unaided eyes from a height of $4.0-4.2 \mathrm{~m}$. He estimated an effective search width of $211 \mathrm{~m}(n=55, \mathrm{CV}$ $=0.11$ ) for Beaufort $0-2$ and estimated the probability of seeing a trackline 


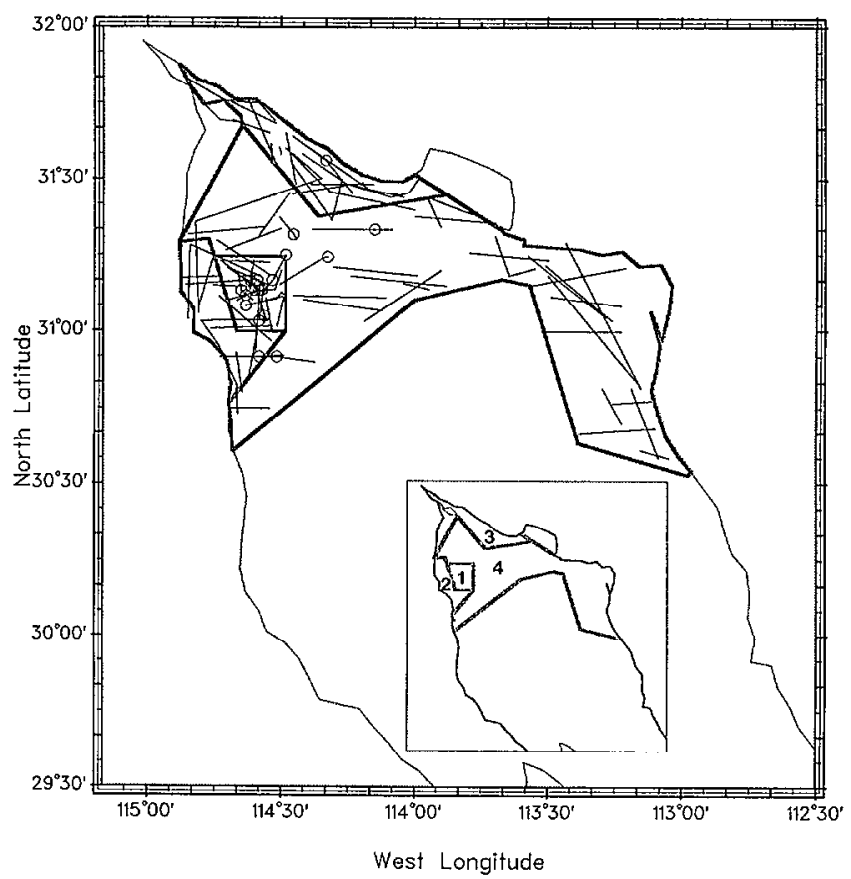

Figure 1. Transect lines, vaquita sighting locations, and geographic strata used in analyses for the 1986-1988 boat surveys.

group to be $0.53(\mathrm{CV}=0.51)$. Palka (1995) conducted a ship survey for harbor porpoises in the Gulf of Maine using a 32-m vessel with three observers searching by naked eye at a height of $9 \mathrm{~m}$ and three additional observers searching by naked eye at a height of $14 \mathrm{~m}$. In "good weather conditions" during her study, the lower observer team was estimated to have an effective search width of $296 \mathrm{~m}(\mathrm{CV}=0.15)$ and a probability of seeing a group on the trackline of $0.39(\mathrm{CV}=0.17)$ (based on an average of her direct duplicate estimates for offshore strata). In summary, harbor porpoise surveys, using a variety of different vessels, have yielded estimates of effective search widths of $143-370 \mathrm{~m}$ and estimates of $g(0)$ from 0.4 (with three observers on small-tomedium-sized vessels) to 0.78 (with five observers on a large ship).

To estimate vaquita abundance from Silber's boat surveys, we use the estimate of effective search width $(211 \mathrm{~m}, \mathrm{CV}=0.11)$ and the probability of seeing a trackline group $(0.53, \mathrm{CV}=0.51)$ from the harbor porpoise survey in Washington (Calambokidis, in press) because the vessel used in that survey was most similar to that used by Silber. The resulting estimate of abundance from Silber's $1986-1988$ boat surveys is $503(\mathrm{CV}=0.63,95 \% \mathrm{CI}=163-$ 1,551) (Table 1).

\section{Estimate \#2: 1988-1989 Aerial Surveys}

Aerial surveys were conducted for vaquitas in May 1988 and September 1989 (Silber and Norris 1991). Transects covered 1,743 km in "calm" sea state 


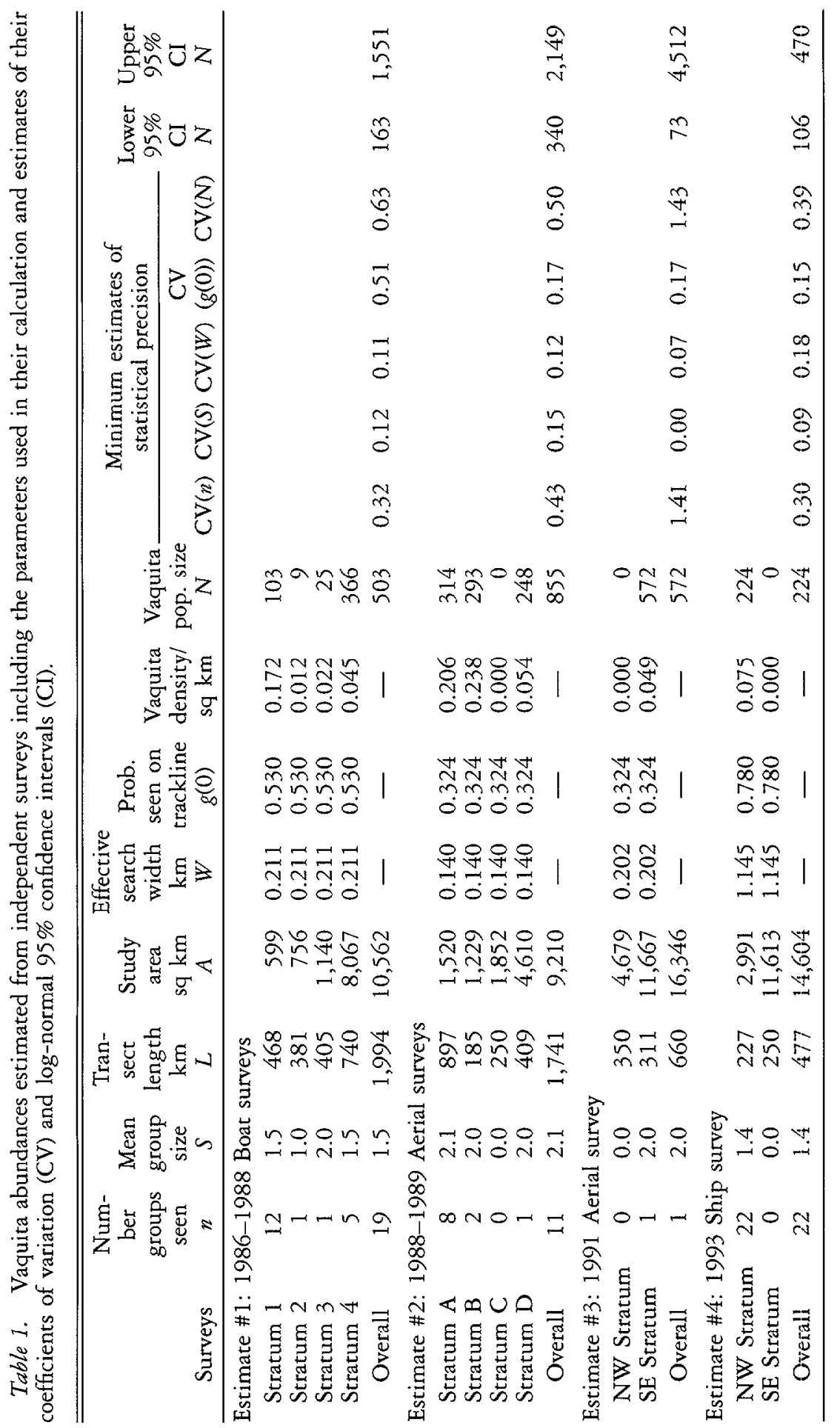




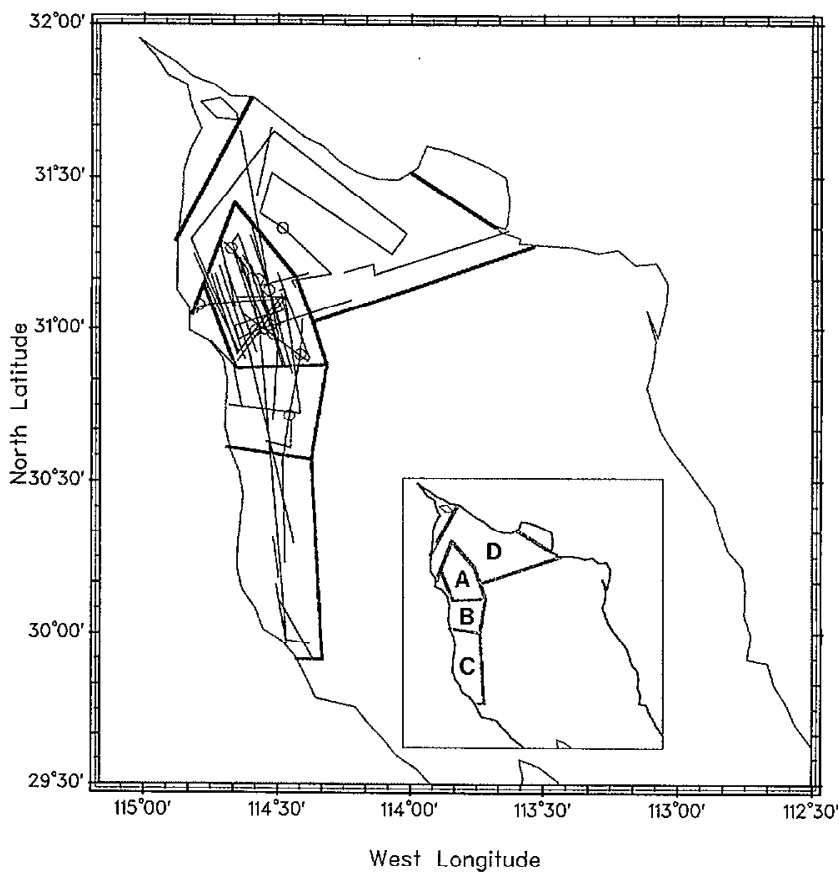

Figure 2. Transect lines, vaquita sighting locations, and geographic strata used in analyses for the 1988-1989 aerial surveys.

conditions (Beaufort 0-2). Effort was concentrated non-randomly in areas which were expected to have higher vaquita density, so effort segments were post-stratified to give four strata with approximately uniform survey effort (Strata A-D, Fig. 2). Line-transect methods were not used on these surveys, and perpendicular sighting distances were not measured; therefore, as with the previous boat survey, $W$ and $g(0)$ were estimated from surveys for harbor porpoises.

Harbor porpoise aerial surveys have estimated the effective search width (W) to be $140 \mathrm{~m}$ ( $n=109, \mathrm{CV}=0.12)$ for 1989 surveys in Washington and Oregon (Turnock et al., in press, as re-estimated by Calambokidis et al. 1993a), $203 \mathrm{~m}(n=494, \mathrm{CV}=0.07)$ for 1990-1991 surveys in Washington and Oregon (Calambokidis et al. 1993a), and $201 \mathrm{~m}$ for 1986-1993 surveys in California ( $n=635, \mathrm{CV}=0.04$ ) (Barlow and Forney 1994). All three surveys were similar to the vaquita surveys in that they were flown at similar altitudes $(152-213 \mathrm{~m}, 500-700 \mathrm{ft})$ and used high-wing aircraft. Here we assume an effective search width of $140 \mathrm{~m}(\mathrm{CV}=0.12)$ for the vaquita surveys because, like the vaquita surveys, the Turnock et al. (in press) study used only two side-window observers and the other two studies used a center belly-window observer in addition to two side-window observers.

The most notable difference between the Turnock et al. survey and the vaquita surveys is that bubble windows were used on the former, allowing a 


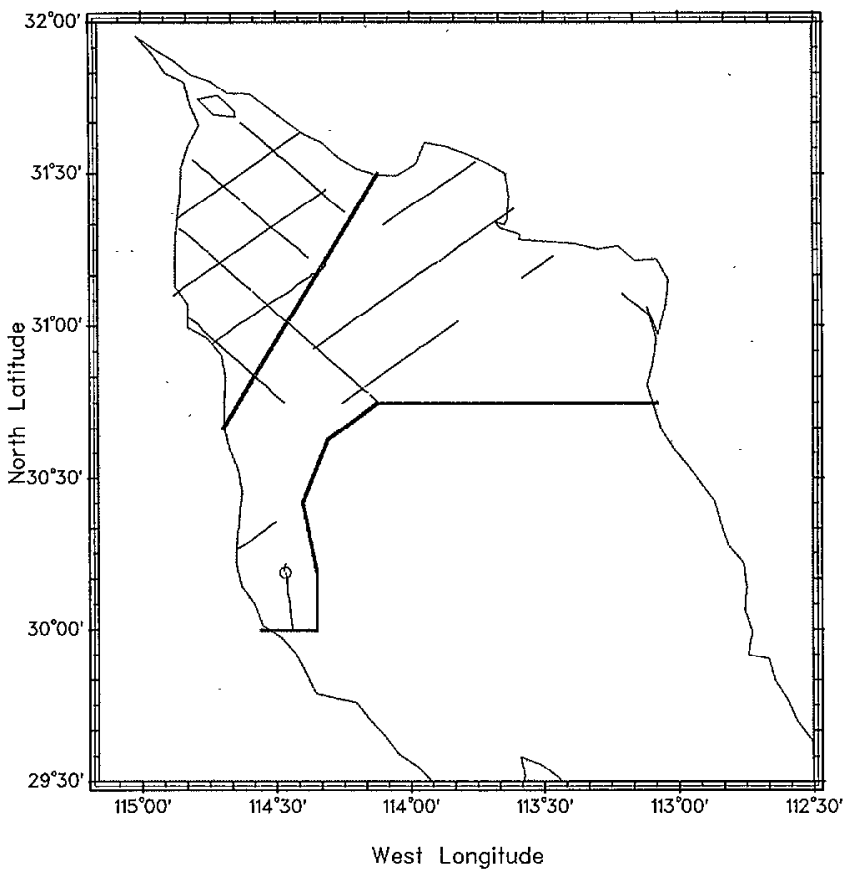

Figure 3. Transect lines, vaquita sighting location, and geographic strata used in analyses for the 1991 aerial survey.

better view of the region close to the trackline, where porpoises are likely to be more easily seen. We use an estimate of $g(0)=0.324(\mathrm{CV}=0.17)$ bascd on the measured fraction of trackline harbor porpoises that were seen during experiments using land-based validation of aerial observations in northern $\mathrm{Pu}$ get Sound, Washington (Calambokidis et al. 1993b). 'The abundance of vaquitas based on these aerial surveys is $855(\mathrm{CV}=0.50,95 \% \mathrm{CI}=340$ 2,149) (Table 1).

\section{Estimate \#3: 1991 Aerial Survey}

An aerial survey was conducted for vaquitas in September 1991 by a joint team from the U.S. and Mexican fisheries agencies (Barlow et al. 1993). Exactly the same aircraft and methods were used on this survey as were used on past harbor porpoise surveys in California (Forney et al. 1991, Barlow and Forney 1994) and Oregon and Washington (Calambokidis et al. 1993a). Effort was uniformly distributed in the study area; however, because coverage in "calm" sea states was more complete in some areas, the study area was post-stratified (Fig. 3). Transects totalling $659 \mathrm{~km}$ were completed in "calm" sea state conditions. Only one confirmed sighting was made of a vaquita, so $W$ could not be estimated directly from this survey. Previous surveys with the same aircraft resulted in estimates of effective scarch widths of $201 \mathrm{~m}(n=635, \mathrm{CV}=$ 
0.04) [from 1988-1993 harbor porpoise surveys conducted at $213 \mathrm{~m}(700 \mathrm{ft}$ ) altitude in California-Barlow and Forney 19941 and $202 \mathrm{~m}(n=494, \mathrm{CV}$ $=0.07$ ) [from 1990-1991 harbor porpoise surveys conducted at $183 \mathrm{~m}(600$ $\mathrm{ft}$ ) in Oregon and Washington-Calambokidis et al. 1993a]. Although the two estimates of effective search width are almost identical, we use the latter value because the altitude during that survey was the same as during the vaquita survey. We assume that $g(0)=0.324(\mathrm{CV}=0.17)$ by analogy to the harbor porpoise (Calambokidis et al. 1993b). The resulting abundance estimate for vaquitas is $572(\mathrm{CV}=1.43,95 \% \mathrm{CI}=73-4,512)$ (Table 1$)$.

\section{Estimate \#4: 1993 Ship Survey}

A ship survey for cetaceans was conducted in the Gulf of California and in Pacific waters of California and Baja California in fall 1993 using a 52-m National Oceanographic and Atmospheric Administration (NOAA) research vessel (Mangels and Gerrodette 1994). Transect lines in the Gulf were spaced at even intervals of $30 \mathrm{~min}$ longitude and were oriented north/south to avoid morning and evening sun glare. In the area where vaquitas had been previously seen, additional transect lines spaced at 7.5-min intervals were added between the 20 - and $40-\mathrm{m}$ isobaths specifically to survey for vaquitas. We therefore post-stratified the survey area into a northwestern stratum with transects spaced at $7.5 \mathrm{~min}$ and a southeastern stratum with transects spaced at $30 \mathrm{~min}$ (Fig. 4). Transect lines completed in the eastern part of the northern Gulf were excluded because they were surveyed in rough seas (Beaufort 4 or greater). The primary observation team consisted of three observers searching from the flying bridge of the vessel at a height above the water of approximately 10 m: two observers searching through $25 \times$ pedestal-mounted binoculars and one observer (also designated data recorder) searching by naked eye and $7 \times$ binocular. In addition, two or three independent observers searched using naked eyes and $7 \times$ and $25 \times$ binoculars. Sightings made by independent observers were not recorded unless they were clearly missed by the three primary observers.

For purposes of analysis, we included only transects covered in Beaufort sea states $0-2$, and we combined the primary and independent observer sightings for estimating $W$. Six line-transect models (hazard rate, hazard rate with cosine adjustments, hazard rate with polynomial adjustments, half-normal with Hermite polynomial adjustments, half-normal with cosine adjustments, and uniform with cosine adjustments) were fit to ungrouped perpendicular sighting distance data (Buckland et al. 1993). Based on the Akaike Information Criterion (AIC) (Akaike 1973), the best fit was obtained using the half-normal model with a second-order cosine term, ${ }^{1}$ and the effective search width was

\footnotetext{
${ }^{1}$ Preliminary estimates of vaquita abundance from the 1993 ship survey were reported by $\mathrm{T}$. Gerrodette based only on the hazard rate model (working paper SC/46/O17 submitted to the 1994 meeting of the International Whaling Commission's Scientific Committee). That model gave a higher estimate of $f(0)$ and produced a higher estimate of vaquita abundance, but it did not fit the data as well as the half-normal/cosine model.
} 


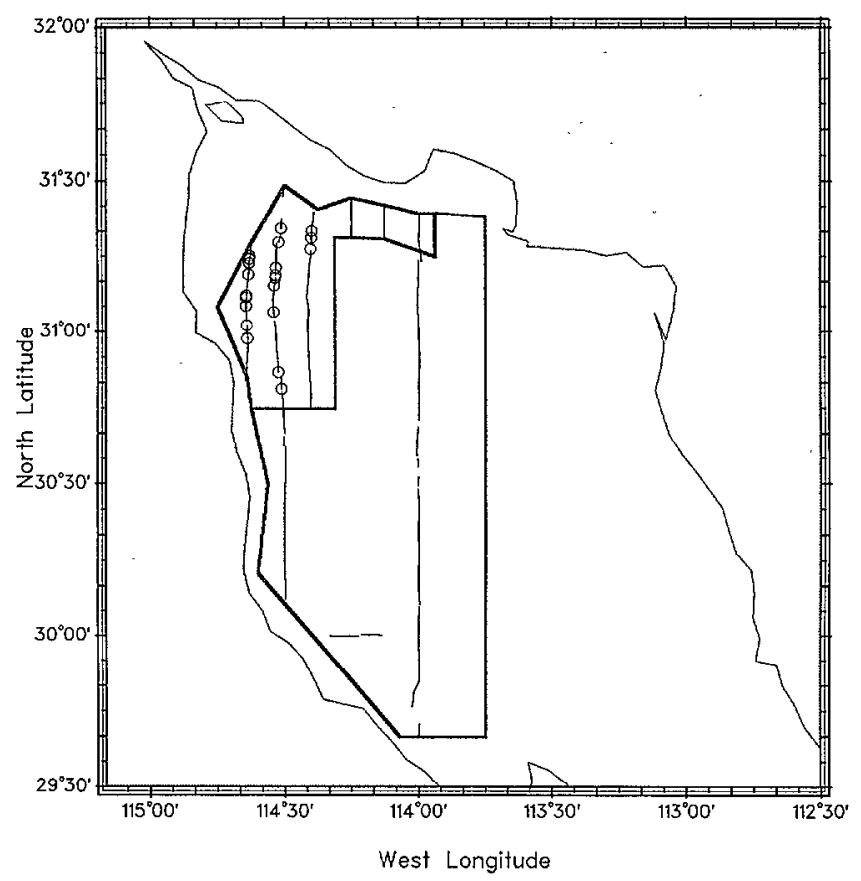

Figure 4. Transect lines, vaquita sighting locations, and geographic strata used in analyses for: the 1993 ship survey.

estimated to be $1.145 \mathrm{~km}\left(f(0)=0.874 \mathrm{~km}^{-1}, \mathrm{CV}=0.18\right.$ ) (Fig. 5). We assume that $g(0)$ is equal to $0.78(\mathrm{CV}=0.15)$, the value measured for harbor porpoises using the identical survey vessel and five observers searching with $7 \times$ binoculars and naked eyes (Barlow 1988). The regression of the logarithm of group size on $g(0)$ produced a bias-corrected (Buckland et al. 1993) group size estimate of 1.4 . The estimated abundance of vaquitas from this survey is $224(\mathrm{CV}=0.39,95 \% \mathrm{CI}=106-470)($ Table 1$)$.

\section{Trends in Abundance}

The results of the four independent analyses of vaquita abundance were combined using a weighted regression to obtain an estimate of the rate of change in vaquita abundance during this time series. Typically, population growth or decline is roughly exponential; therefore, we regressed the natural logarithm of the time series of abundance estimates against year as the independent variable. To account for differences in the precision of the four estimates, we weighted each point by the inverse of its variance. The variance of the natural logarithm of each estimate, $N$, was estimated as $\ln \left(1+\mathrm{CV}^{2}(N)\right)$. The resulting least-squares regression line (Fig. 6) has a slope of $-0.195(95 \%$ $\mathrm{CI}=-0.566$ to +0.176$)$ which is not significantly different from zero $(P=$ $0.15,2$-tailed). After back-transforming, the rate of decline is estimated to be $-17.7 \%$ per year $(95 \% \mathrm{CI}=-43.2 \%$ to $+19.3 \%)$. 


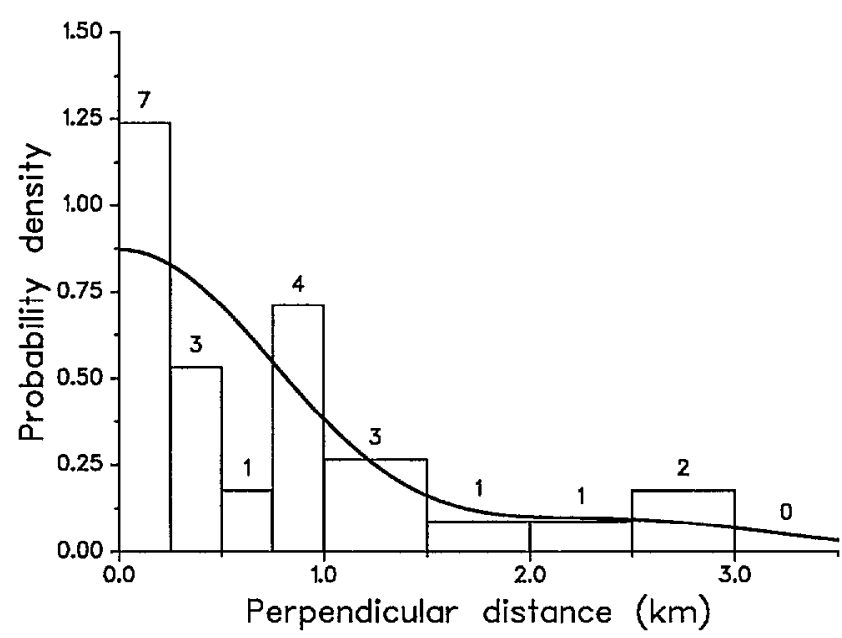

Figure 5. Distribution of perpendicular sighting distances and maximum likelihood fit of a probability density function to those data using a half-normal model with cosine adjustment terms. Numbers over histogram bars indicate number of sightings.

\section{DisCUSSION}

As noted by Taylor and Gerrodette (1993), precise estimates of abundance are difficult to obtain for many endangered species. This problem is exacerbated as the species becomes increasingly rare. This is exactly the time, however, when abundance estimates are most valuable. Often, conservation efforts are delayed because without abundance estimates, many managers will doubt the true conservation status of a species. Doubt paralyzes management actions when difficult decisions are needed to protect a species. It is likely that the lack of published abundance estimates has delayed conservation measures for vaquitas.

Each of the population estimates presented here could easily be faulted for many deficiencies. Sample sizes are small in all cases, and none of the estimates are very precise. Systematic line-transect methods were used on only two of the surveys. All the estimates rely heavily on parameters that are taken from studies of another species in different areas. It is largely because of these weaknesses that a published estimate of the size of the vaquita population has not previously existed.

The strength of our analyses becomes evident only from looking at all of the estimates in the aggregate (Fig. 6). Despite imprecision and many potential sources of bias, all of the estimates fall within a rather narrow range (224855). All the estimates indicate that the abundance of the species is at a critically low level.

\section{Likely Biases}

The estimate of abundance from the 1986-1988 boat surveys (Estimate \#1) may be biased because the vessel used to estimate $W$ and $g(0)$ (for harbor 


\section{Vaquita Abundance and $80 \%$ C.I.'s}

(with weighted log-regression)

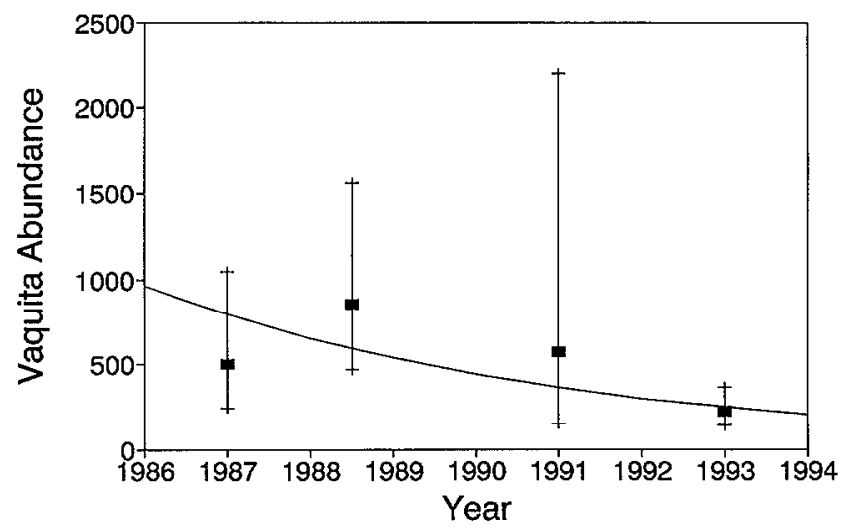

Figure 6. Summary of four independent estimates of vaquita abundance with error bars indicating log-normal $80 \%$ confidence intervals. Exponential regression line represents linear least-squares fit to the natural logarithm of the estimates weighted by the inverse of their log-transformed variances.

porpoises) was larger and observation height was higher than for the vaquita surveys. On the other hand, observation conditions in the northern Gulf of California are often better for a given Beaufort sea state than conditions found during the harbor porpoise surveys summarized above (JB, personal observation). In particular, sea swell is minimal in the northern Gulf, and therefore the probability of seeing a distant sighting might be greater there. On balance, observation height is likely to be more important; therefore, the effective search width would be less than $211 \mathrm{~m}$ and the probability of seeing a trackline group would be less than $53 \%$. Both of these factors might result in a biased underestimate of vaquita abundance.

The abundance estimates from the 1988-1989 aerial surveys (Estimate \#2) are likely to be biased by two factors. The effective search width for the vaquita surveys is likely to be less than that for the harbor porpoise surveys (140 m) because the aircraft lacked bubble windows. Also, water in the northern Gulf of California can be extremely turbid, which increases the likelihood that porpoises would be missed by aerial observers. The true value of $g(0)$ for vaquitas is therefore likely to be less than the assumed value of 0.324 (which was measured for harbor porpoises in clearer waters). The overall effect of both of these factors would be to underestimate vaquita abundance.

The 1991 aerial survey estimate of abundance (Estimate \#3) is also likely to be biased low because waters in the northern Gulf are extremely turbid and $g(0)$ is probably overestimated. In this case, however, there is no reason to think that the assumed value for $W$ is biased; the same methods were used on this survey that were used to estimate $W$ on harbor porpoise surveys. However, sample size for this estimate is very small, and although this estimate 
may be less biased than the 1988-1989 aerial estimate, it is also much less precise. Overall, abundance is likely to be underestimated.

The estimate of vaquita abundance from the 1993 ship survey (Estimate \#4) may be biased because sighting conditions (especially swell height) in the northern Gulf were generally better than conditions when $g(0)$ was estimated for harbor porpoises off the coast of California. Also, the use of both $7 \times$ and $25 \times$ binoculars in 1993 increases the probability that a group of trackline animals will be seen by at least one method [only $7 \times$ binoculars were used in estimating $g(0)]$. For these reasons, $g(0)$ may be underestimated and abundance overestimated. Although this estimate does not include waters in the northern Gulf less than $20 \mathrm{~m}$ in depth, other surveys (Silber 1990a, b; Gerrodette $e t$ al. 1995) have included these waters and have found very low vaquita densities. When the effort from the 1986-1989 boat and aerial surveys reported here (Fig. 1, 2) is combined, the number of vaquita sightings per 100 $\mathrm{km}$ surveyed was 1.45 inside the 1993 ship survey area and 0.16 outside that area. Because most of the known vaquita habitat was surveyed in 1993, and because vaquita density outside the surveyed area is approximately $11 \%$ of the density inside that area, the bias due to unsurveyed areas is probably very small. Overall, this estimate is likely to be the most accurate and precise of the four estimates, because it was designed as a systematic line-transect survey, $W$ was estimated from survey data, and a relatively large number of sightings was obtained.

All four of the estimates may be biased low to some degree because some vaquitas are doubtlessly found outside the geographic strata that we used. In all of these cases, however, the surveys covered the vast majority of the known range of vaquitas, and this source of bias is likely to be very small.

Because the estimates of $\mathrm{CV}(W)$ and $\mathrm{CV}(g(0))$ for the boat and aerial surveys were taken from studies of another species with larger sample sizes, they are clearly not representative of the statistical uncertainty associated with $W$ and $g(0)$ for vaquitas. These values and the resulting estimate of $\mathrm{CV}(N)$ are useful only as minimum estimates of statistical uncertainty.

\section{Declining Vaquita Abundance}

Taken together, the four estimates reported here indicate that the vaquita population is declining at about $18 \%$ per year. The estimated decline is not statistically significant (at $\alpha=0.05$ ), but it is very difficult to document statistically significant declines for rare species (Taylor and Gerrodette 1993). Although it has long been suspected that the vaquita population is declining, these are the first quantitative data that are consistent with this suspicion. The $95 \%$ confidence interval on the estimated rate of decline includes 0.0 , which means there is some probability the population is not declining. However, the wide confidence interval is not surprising given the imprecision of the estimates and the short span of time. The difficulty of obtaining a confidence interval which does not include 0.0 can be gauged by estimating the statistical power. If a population were actually declining at $20 \%$ per year over 
a six-year period, the probability is only 0.13 that the decline will be detected (with statistical significance) given four population estimates with the variability reported here. Even if the true rate of decline were $30 \%$ per year, the probability that the decline will be statistically significant is only 0.20 [from program TRENDS (Gerrodette 1993)].

A high rate of decline is, however, consistent with what is known about the population size (from this study) and what is known about the rates of incidental mortality in gillnet fisheries (D'Agrosa 1995, Vidal 1995). For 1993-1994, the mortality of vaquitas from gillnet fishing out of the port of El Golfo de Santa Clara, Sonora, Mexico, has been estimated as 39-84 per year (D'Agrosa 1995). El Golfo de Santa Clara is only one of three major fishing ports within the range of vaquitas (the others are San Felipe, Baja California Norre and Puerto Peñasco, Sonora). Even if fishing effort in those other ports is less than in El Golfo de Santa Clara, the total vaquita mortality due to gillnet fishing may be greater than 100 per year. Given these levels of mortality, lower reproductive potential than for other phocoenids (Hohn et al. 1996 ), and the 1993 population estimate of 224 , we expect decreases in vaquita abundance to continue in the near future.

\section{ACKNOWLEDGMENTS}

We thank M. Newcomer, H. Perez-C., G. Ellis, A. Robles, L. Fleischer, K. Forney, O. Maravilla, K. Mangels, G. Aldana, J. Cotton, D. Gendron, D. Kinzey, P. Olson, R. Pirman, and J. Rivers for all of their help on the surveys. This manuscript was improved by helpful comments from S. Buckland, J. Calambokidis, K. Forney, D. Neal, W. Perrin, B. Taylor, and an anonymous referee.

\section{Literature Cited}

AKaIKe, H. 1973. Information theory and an extension of the maximum likelihood principle. Pages 267-281 in B. N. Petran and F. Csàaki, eds. International Symposium on Information Theory, 2nd Edition. Akadèemiai Kiadi, Budapest, Hungary.

BARLOW, J. 1986. Factors affecting the recovery of Pbocoena sinus, the vaquita or Gulf of California harbor porpoise. Southwest Fisheries Center Administrative Report LJ-86-37. [Available from Southwest Fisheries Science Center, P. O. Box 271, La Jolla, CA 92038.] 19 pp.

BARLOW, J. 1988. Harbor porpoise (Phocoena phocoena) abundance estimation in California, Oregon and Washington: I. Ship surveys. Fishery Bulletin 86:417-432.

BARLOW, J., AND K. A. FORNEY. 1994. An assessment of the 1994 status of harbor porpoise in California. NOAA Technical Memorandum NOAA-TM-NMFSSWFSC-205. $17 \mathrm{pp}$.

Barlow, J., C. Oliver, T. D. Jackson and B. L. Taizor. 1988. Harbor porpoise (Pbocoena phocoena) abundance estimation in California, Oregon and Washington: II. Aerial surveys. Fishery Bulletin, U.S. 86:433-444.

Barlow, J., L. Fleischer, K. A. Forney and O. Maravilla-Chavez. 1993. An experimental aerial survey for vaquita (Pbocoena sinus) in the northern Gulf of California, Mexico. Marine Mammal Science 9:89-94.

BJørge, A., AND G. P. Donovan, EDs. 1995. Biology of the phocoenids. Report of the International Whaling Commission (Special Issue 16). $552 \mathrm{pp}$. 
Brownell, R. L., JR. 1986. Distribution of the vaquita, Phocoena sinus, in Mexican waters. Marine Mammal Science 2:299-305.

Buckland, S. T., D. R. Anderson, K. P. Burnham and J. L. Laake. 1993. Distance sampling: Estimating abundance of biological populations. Chapman and Hall, London, U.K.

Burnham, K. P., D. R. Anderson and J. L. LaAke. 1980. Estimation of density from line transect sampling of biological populations. Wildlife Monograph No. 72. $202 \mathrm{pp}$.

Calambokidis, J. In press. Vessel surveys for harbor porpoise off the Washington coast. In H. Kajimura, ed. Harbor porpoise interactions with Makah salmon set net fishery in coastal Washington waters, 1988-89. National Marine Mammal Laboratory, 7600 Sand Point Way, N.E., Seattle, WA 98115-0070. NOAA Technical Report.

Calambokidis, J., C., Ewald, G. H. Steiger, S. M. Cooper, I. D. Szczepaniak and M. A. WebBer. 1990. Harbor porpoise studies in the Gulf of the Farallones. Final Contract Report to the Gulf of the Farallones National Marine Sanctuary, Fort Mason Center, Bldg. 201, San Francisco, CA 94123. 58 pp.

Calambokidis, J., J. C. Cubbage, J. R. Evenson, S. D. Osmek, J. L. Laake, P. J. Gearin, B. J. Turnock, S. J. Jefrries and R. F. Brown. 1993a. Abundance estimates of harbor porpoise in Washington and Oregon waters. Final Contract Report \#40ABNF201935 available from National Marine Mammal Laboratory, 7600 Sand Point Way, N.E., Seattle, WA. 55 pp.

Calambokidis, J. C., J. R. Evenson, J. C. Cubbage, S. D. Osmek, D. Rugh and J. L. LAAKE. 19936. Calibration of sighting rates of harbor porpoise from aerial surveys. Final Contract Report to the National Marine Mammal Laboratory, 7600 Sand Point Way, N.E., Seattle, WA. 41 pp.

D'Agrosa, C. E. 1995. Mortalidad incidental de la vaquita (Pbocoena sinus) en actividades pesqueras del alto Golfo de California, México, 1993-94. Tesis de Maestra en Ciencias, Instituto Technológico y de Estudios Superiores de Monterrey, Guaymas, Sonora, México. 112 pp.

Forney, K. A., D. A. Hanan and J. Barlow. 1991. Detecting trends in harbor porpoise abundance from aerial surveys using analysis of covariance. Fishery Bulletin, U.S. 89:367-377.

GerRodette, T. 1993. Trends: Software for a power analysis of linear regression. Wildlife Society Bulletin 21:515-516.

Gerrodette, T., L. A. Fleischer, H. Peréz-Cortés and B. Villa-R. 1995. Distribution of the vaquita, Phocoend sinus, based on sightings from systematic surveys. Report of the International Whaling Commission (Special Issue 16):273-281.

Hohn, A. A., A. J. Read, S. Fernández, O. Vidal and L. T. Findley. 1996. Life history of the vaquita, Phocoena simus (Phocoenidae, Cetacea). Journal of Zoology, London 239:235-251.

KunnowsKA, M., ED. 1991. Dolphins, porpoises and whales of the world. The IUCN Red Data Book. International Union for the Conservation of Nature and Natural Resources, Gland, Switzerland and Cambridge, United Kingdom.

LaAke, J. L., S. T. Buckiand, D. R. Anderson and K. P. Burnham. 1993. DISTANCE user's guide. Colorado Cooperative Fish and Wildlife Research Unit, Colorado State University, Fort Collins, CO 80523.

Mangels, K. F., AND T. Gerrodette. 1994. Report of cetacean sightings during a marine mammal survey in the eastern Pacific Ocean and the Gulf of California aboard the NOAA ships McArtbur and David Starr Jordan July 28-November 6, 1993. NOAA Technical Memorandum NOAA-TM-NMFS-SWFSC-221. 88 pp.

PAIKA, D. 1995. Abundance estimate of the Gulf of Maine harbor porpoise. Report of the International Whaling Commission (Special Issue 16):27-50.

Silber, G. K. 1990a. Distributional relations of cetaceans in the northern Gulf of 
California with special reference to the vaquita, Phocoena sinus. Ph.D. thesis, University of California, Santa Cruz. 145 pp.

Silber, G. K. 1990b. Occurrence and distribution of the vaquita Phocoena sinus in the northern Gulf of California. Fishery Bulletin, U.S. 88:339-346.

Silber, G. K., AND K. S. Norris. 1991. Geographic and seasonal distribution of the vaquita, Phocoena sinus. Anales Instituto Biología de Universidad Nacional Autónoma, Mexico, Seria Zoologia 6(2):263-268.

Silber, G. K., M. W. Newcomer and G. J. Barros. 1988. Observations on the behavior and ventilation cycles of the vaquita, Phocoena sinus. Marine Mammal Science 4:62-67.

TAYLOR, B. L., AND T. Gerrodette. 1993. The uses of statistical power in conservation biology: The vaquita and northern spotted owl. Conservation Biology 7:489-500.

Turnock, B. J., S. J. JefrRies AND R. F. Brown. In press. Population abundance of harbor porpoise (Pbocoena phocoena) from aerial surveys off the coast of Oregon, Washington, Strait of Juan de Fuca, and Vancouver Island. In $\mathrm{H}$. Kajimura, ed. Harbor porpoise interactions with Makah salmon set net fishery in coastal Washington waters, 1988-89. National Marine Mammal Laboratory, 7600 Sand Point Way, NE., Seattle, WA. NOAA Technical Report.

VIDAL, O. 1993. Aquatic mammal conservation in Latin America: Problems and perspectives. Conservation Biology 7:788-795.

VIDAL, O. 1995. Population biology and incidental mortality of the vaquita, Phocoena sinus. Report of the International Whaling Commission (Special Issue 16):247272.

VILLA-R, B. 1993. Recovery plan for the vaquita, Pbocoena sinus. NTIS Report PB93169415. Report to the U.S. Marine Mammal Commission, 1825 Connecticut Ave. N.W., Washington, DC 20009. 36 pp.

Received: 12 January 1996

Accepted: 10 April 1996 